\title{
Social Security Death Index
}

National Cancer Institute

\section{Source}

National Cancer Institute. Social Security Death Index. NCI Thesaurus. Code C107424.

A publically-accessible database derived from the Social Security Administration's (SSA)

Death Master File Extract. It includes a listing of the vital statistics of a majority of decedents reported to the SSA since 1962. 